\title{
MODIFICATION OF ENGINE CONTROL UNIT DATA AND SELECTED VEHICLE CHARACTERISTICS
}

UDC: $629.33: 629.3 .058$

Original scientific paper

https://doi.org/10.18485/aeletters.2019.4.4.3

\author{
František Synák $^{1 *}$, Ján Synák ${ }^{1}$, Tomáš Skrúcaný ${ }^{1}$, Saša Milojević \\ ${ }^{1}$ University of Žilina, Faculty of operation and economics of transport and communications, Department of \\ road and urban transport, Slovakia \\ ${ }^{2}$ University of Kragujevac, Faculty of Engineering, Department for Motor Vehicles and IC Engines, Serbia
}

\begin{abstract}
:
Data stored in the memory of the engine control unit can be adjusted and modified in order to change some vehicle features. The purpose of the article is to determine the impact of such adjustments in the engine control unit on selected vehicle characteristics. These include the engine power and torque depending on the engine speed and fuel consumption. The measurements were performed under laboratory conditions in order to achieve the highest possible accuracy. The results show the possibilities of dynamic vehicle characteristics' improvement without having specific impact on the fuel consumption.
\end{abstract}

\author{
ARTICLE HISTORY \\ Received: 24.09.2019. \\ Accepted: 05.12.2019. \\ Available: 31.12.2019.

\section{KEYWORDS} \\ Engine control unit, fuel \\ consumption, engine power \\ and torque, vehicle
}

\section{INTRODUCTION}

Data adjustments in the engine control unit (ECU) or engine control module (ECM) are performed quite often. ECU controls a series of actuators on an internal combustion (IC) engine to ensure optimal performance. It does this by reading values from a multitude of sensors within the engine, interpreting the data using multidimensional performance maps, and adjusting the engine actuators. Before ECUs, air-fuel mixture, ignition timing, and idle speed were mechanically set and dynamically controlled by mechanical and pneumatic means [1].

If the ECU has control over the fuel lines, then it is referred to as an electronic engine management system (EEMS). Fuel injection system has the major role to control the engine's fuel supply. The whole mechanism of the EEMS is controlled by a stack of sensors and actuators.

The most common adjustments can be seen in the compression ignition $(\mathrm{Cl})$ or diesel engines with pressure charging [2] due to easy increase of air amount into the cylinders as well as fuel amount injected in their same proportion, and thus, to reach higher engine power and torque [3]. If the above mentioned proportion was not the same, it could lead to an excessive smoke opacity in the engine exhaust [4].

The purpose of this research article is to determine the impact of control data adjustments in the ECU on selected vehicle characteristics. These include the course of the engine power and torque curves, maximum power and torque, and brake specific fuel consumption (BSFC) as well as fuel consumption per particular distance travelled.

\section{EXPERIMENTAL SETUP}

The course of the engine power and torque together with fuel consumption per particular distance and BSFC were all measured before and after the ECUs data adjustment.

The experiments were carried out at the Laboratory for IC engines at the Department of road and urban transport, University of Žilina, on 
a single-cylinder four-stroke, and air-cooled diesel engine (type: BLS; Maker: VW).

\subsection{Vehicle used for measuring}

Technical data of vehicle and engine used during measurements are shown in the Table 1.

Table 1. Technical data of the experimental vehicle [5]

\begin{tabular}{|c|c|}
\hline Description & Specification \\
\hline Vehicle & ŠKODA OCTAVIA \\
\hline & 1.9 TDI BLS (VW) \\
Engine specification & Diesel with turbocharger \\
& $77 \mathrm{~kW}$ at $4000[1 / \mathrm{min}]$ \\
& $250 \mathrm{Nm}$ at $1900[1 / \mathrm{min}]$ \\
\hline \multirow{2}{*}{ Fuel injection system } & Unit Injector System (UIS) \\
& Direct injection \\
\hline Gearbox & Automatic with 6 speed, DSG \\
\hline
\end{tabular}

\subsection{Measurement of the engine power and torque}

The measurements were performed at the cylinder test-rig MAHA MSR 1050 according to its operating instructions. The engine was also provided with automatic gearbox (trademark DSG) which also allowed manual gear shifting.

Firstly, it was fixed at the vehicle dynamometer, and after the engine conditioning with having the acceleration pedal fully applied and using the fifth gear speed, the maximum engine speed was reached, and thus, the engine power could be measured.

After this, the driver shifted neutral gear $(\mathrm{N})$ and let the wheels with driving systems slow down freely. There, the mechanical losses between gearbox shafts (permanent locked clutch) and vehicle dynamometer were measured. In the case of a manual gearbox mode, the torque flow of the engine is interrupted in the clutch. In the case of an automatic gearbox DSG, it is interrupted in the transmission by shifting in $\mathrm{N}$ mode.

Subsequently, the cylinder test-rig station computer calculated the course of the engine torque curve on the basis of the engine speed and its power curve's course [6].

\subsection{Measurement of fuel consumption}

Fuel consumption was measured by the volume flow meter type AIC 1204 of which the measurement accuracy is declared by manufacturer (also with declaration of accuracy)
[7]. Operating principles of flow meter can be seen in the Fig.1.
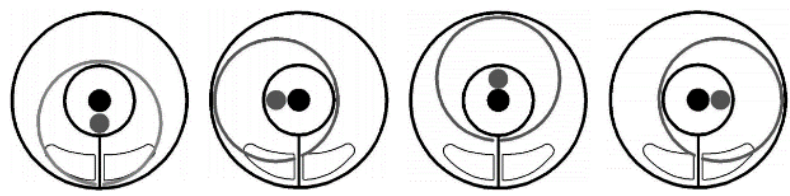

Fig. 1. AIC 1204 flow meter operating principles [7]

A fuel flowing by the flow meter causes a rotation of movable piston element. Each rotation is being recorded while certain volume of fuel flowed corresponds to each rotation.

Connection of flow meter to vehicle during measurement is shown in the Fig. 2 .

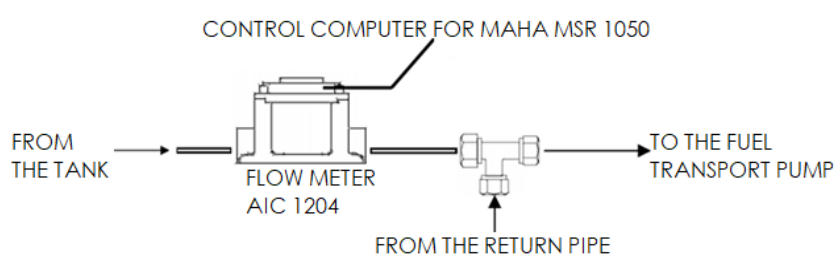

Fig. 2. AIC 1204 flow meter connection for fuel consumption measurement

The fuel from the vehicle used is returned to the tank from the fuel transport pump placed in the vehicle engine. In order to measure the fuel consumption, it is necessary to connect the return fuel line between the flow meter and fuel transport pump. By this, the fuel instead of being transported to the fuel tank and measured as consumed will return into the fuel transport tank. When connecting AIC 1204 flow meter according to Fig.2, it needs to cool the fuel in the return pipe down. The fuel in the pump is warmed by the engine, and, during its return to the tank, it is cooled by the air flown around. The fuel is then mixed with the other fuel cooled in the tank. During connection of return fuel line into the fuel transport tank, it would lead to heating of the fuel to $150^{\circ} \mathrm{C}$ and more in a few seconds, and, it is unfavourable for the components coming into contact with fuel [8]. Therefore, it must be a metal pipe implemented during measurement. The metal pipe is put into a container with cold water and, at the same time, the fuel temperature must be controlled by diagnostic software which is communicating with the ECU. Since the volume fuel flow meter was used during fuel measurement, a change in the fuel temperature would have cause also a change in the measurement accuracy [9]. 
The fuel consumption has been measured at the first, third and fifth gear, at the engine speed of $(1500 ; 2000 ; 2500$ and 3000$)[1 / \mathrm{min}]$.

The cylinder of the vehicle dynamometer MAHA MSR 1050 has had a set load simulating the driving resistances with the value of (250; 500; 750 and 1000) $N$. These values of driving resistance are of common occurrence during vehicle operation [10].

During each measurement at selected gear and value of driving resistances used, it was necessary to keep the chosen engine speed constant for the period of at least $120 \mathrm{~s}$. The data on the engine speed, fuel consumed and distance travelled were saved in the control computer of MAHA MSR 1050 cylinder test-rig. Then, the fuel consumption in litres per 100 kilometres was calculated from these values.

There were also the driving speed and value of driving resistances, i.e. value of load set on the cylinders recorded during measurements. Thus, it was possible to calculate the wheel power needed for overcoming the driving resistances. It was calculated according to relation (1):

$$
P_{v}=\frac{V}{3.6} \cdot F_{d r}
$$

Where is:

- $P_{v}$ - cylinder power needed for overcoming the set driving resistances, $W$;

- $V$ - driving speed, $[\mathrm{km} / \mathrm{h}]$; and

- $F_{d r}$-driving resistance, $N$, [11].

Besides giving the fuel consumption per certain distance travelled, BSFC was given, too. In order to calculate BSFC, it had to be the power directly from the engine determined as there are power losses between the engine and wheels due to the occurrence of internal resistances [12] as well as the tyre rolling down of the vehicle dynamometer [13]. In order to calculate the engine power, it was necessary to determine the value of power measured between the gearbox and vehicle dynamometer by measuring the vehicle coast down at the vehicle dynamometer. There, measuring the engine power mode was selected and the vehicle used the first, the third or the fifth gear (manually shifted). The engine speed reached the value at least $4000[1 / \mathrm{min}]$ and then, no gear was shifted in order to activate measuring the vehicle coast down phase. Subsequently, the dynamometer measured the power losses between the engine and vehicle dynamometer as well as the engine output power was calculated. For better transparency, there is an example of calculation of the losses between the cylinders and engine with using the third gear given. Fig. 3 shows the graph with curves of the engine power and power on the wheels.

From the graph in the Fig.3, the value of power on the cylinders (the blue curve) of $48 \mathrm{~kW}$, and the value of power on the engine output (the red curve) of $60 \mathrm{~kW}$ at the engine speed of $2000[1 / \mathrm{min}]$ were deducted. It means that when having the engine speed of 2000 [1/ $\mathrm{min}$ ] and the fifth gear used, the engine power is needed to be increased in comparison with cylinders power by $25 \%$ so as to measure the power on the engine output.

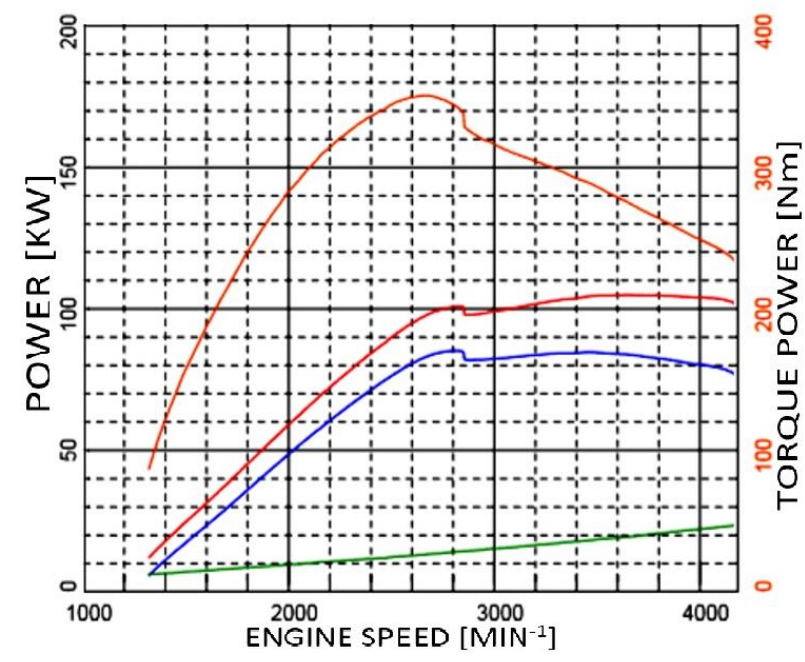

Fig. 3. Power losses between the engine and wheels at the fifth gear used

In such conditions, the vehicle had a speed of $73[\mathrm{~km} / \mathrm{h}]$. If there was a load of $250 \mathrm{~N}$, the cylinders power would have been calculated as (2):

$$
P_{v}=\frac{73}{3.6} \cdot 250=5069 \mathrm{~W}
$$

If the cylinders power was $5069 \mathrm{~W}$, it means that the engine would have had the power $25 \%$ higher, and, thus, with the value of $6336 \mathrm{~W}$. When there is known BSFC for driving $100 \mathrm{~km}$ value measured of $5.4[l / 100 \mathrm{~km}]$, the engine power and speed, it is possible to calculate the BSFC also by the engine. It was calculated according to relation (3) [14]:

$$
m_{p e}=\frac{Q_{100} \cdot \rho}{t \cdot P_{m}}
$$


Where is:

- $m_{p e}$ - BSFC, $[g / k W h]$;

- $Q_{100}$ - amount of fuel consumed after $100 \mathrm{~km}$ travelled, [l/100 km];

- $\rho \quad$ - density of fuel, $\mathrm{kg} \cdot \mathrm{m}^{-3}$;

- $t \quad$ - drive time for $100 \mathrm{~km}, h$; and

- $P_{m}$ - engine power, $W$.

After having substituted these determined and calculated values (4):

$$
m_{p e}=\frac{5.4 \cdot 840}{\frac{100}{39} \cdot 6336}=464[\mathrm{~g} / \mathrm{kWh}]
$$

For each measurement, BSFC was calculated as described above.

\subsection{ECUs data adjustment}

In order to communicate between the portable computer with software needed for data adjusting and ECU, on-board diagnostics (OBD) interface was used. OBD systems give access to the status of the various vehicle subsystems. The vehicle used for measuring and adjusting has included EDC 16 unit with EEPROM memory. The downloaded data are being backed up and used in case if the vehicle does not have its required operational characteristics after data adjustment, or there is not any possibility to upload new adjusted data. Then, the data were optimized and adjusted. During adjustment, it is possible to see particular parameters in the form of 3D graphs.

After data adjustment, these were uploaded into the ECU via OBD interface again [15].

\section{RESULTS}

\subsection{Impact of the ECUs data adjustment on the course of engine power and torque}

The results of the impact of data adjustments in the ECU on the course of engine power and torque are displayed in the Fig.4. The abscissa $X$ axis shows the engine speed in $[1 / \mathrm{min}]$, the left ordinate $Y$ axis shows the engine power in $k W$ and, the right ordinate $Y$ axis shows the engine torque in $\mathrm{Nm}$. The green colour represents the course of engine torque and the red colour represents the course of engine output power. The blue colour, thus, represents the course of engine power on the cylinders. The curves measured before data adjustments have the thin lines and the curves measured after data adjustments have the thicker ones.

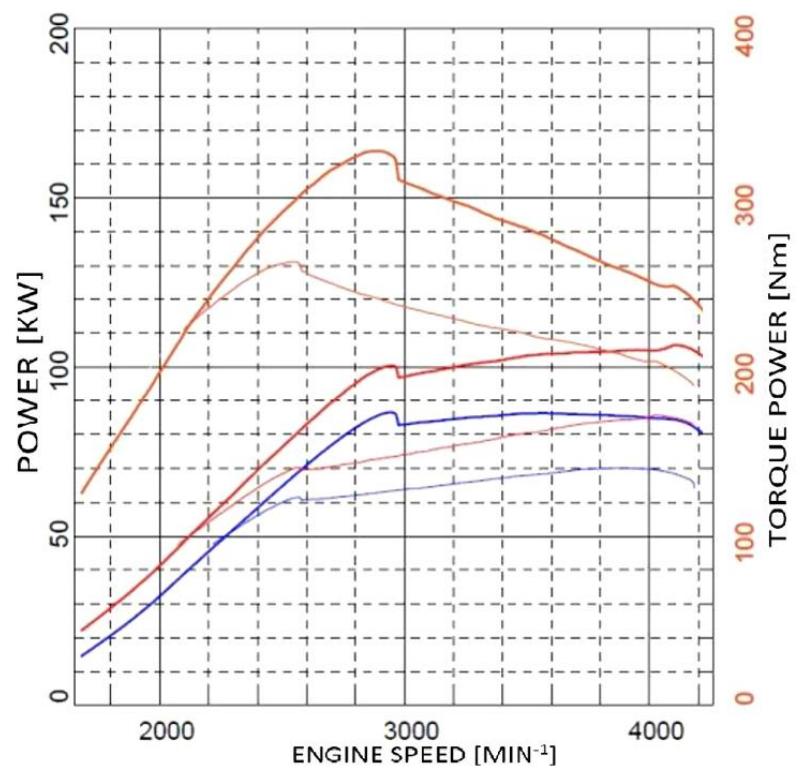

Fig. 4. Impact of the ECUs data adjustment on the course of engine power and torque

As shown in the graph, the maximum engine torque has increased from $262 \mathrm{Nm}$ up to $324 \mathrm{Nm}$ after data adjustment. It is a $23 \%$ increase. The engine can have the maximum torque when having its speed of 2850 [1/min]. When comparing the maximum engine torque at the speed of $2550[1 / \mathrm{min}]$, before the data adjustment, the engine torque elasticity has increased and this has a positive impact when driving uphill with a laden vehicle [16].

Together with torque, the engine power has increased. The maximum engine power before data adjustment was $86 \mathrm{~kW}$ and after data adjustment it was $107 \mathrm{~kW}$. Bearing in mind the engine speed at which the engine reaches its maximum power, the differences in reaching the engine maximum power are not considerable.

\subsection{Impact of the ECUs data adjustment on the amount of fuel consumed for drive $100 \mathrm{~km}$}

The amount of fuel consumed in litres per $100 \mathrm{~km}$ depending on the gear used and the load set on cylinders of dynamometer before the ECUs data adjustment is shown in the Tables 2, 4 and 6 below, and, after the ECUs data adjustment, as shown in the Tables 3, 5 and 7. 
Table 2. Fuel consumption before data adjustment, gear speed 1

\begin{tabular}{|c|c|c|c|}
\hline \multirow{2}{*}{$\begin{array}{c}\text { Driving } \\
\text { resistances, }[N]\end{array}$} & \multicolumn{3}{|c|}{ Engine speed, $[1 / \mathrm{min}]$} \\
\cline { 2 - 4 } & $\mathbf{1 5 0 0}$ & $\mathbf{2 0 0 0}$ & $\mathbf{2 5 0 0}$ \\
\cline { 2 - 4 } & \multicolumn{2}{|c|}{ Fuel consumption, $[l / 100 \mathrm{~km}]$} \\
\hline $\mathbf{2 5 0}$ & 13.8 & 14.7 & 16.0 \\
\hline $\mathbf{5 0 0}$ & 17.9 & 19.8 & 19.9 \\
\hline $\mathbf{7 5 0}$ & 19.8 & 20.2 & 20.1 \\
\hline $\mathbf{1 0 0 0}$ & 20.1 & 20.4 & 20.2 \\
\hline
\end{tabular}

Table 3. Fuel consumption after data adjustment, gear speed 1

\begin{tabular}{|c|c|c|c|}
\hline \multirow{2}{*}{$\begin{array}{c}\text { Driving } \\
\text { resistances, }[N]\end{array}$} & \multicolumn{3}{|c|}{ Engine speed, $[1 / \mathrm{min}]$} \\
\cline { 2 - 4 } & $\mathbf{1 5 0 0}$ & $\mathbf{2 0 0 0}$ & $\mathbf{2 5 0 0}$ \\
\cline { 2 - 4 } & \multicolumn{2}{|c|}{ Fuel consumption, $[l / 100 \mathrm{~km}]$} \\
\hline $\mathbf{2 5 0}$ & 13.2 & 15.3 & 15.2 \\
\hline $\mathbf{5 0 0}$ & 15.8 & 15.7 & 16.1 \\
\hline $\mathbf{7 5 0}$ & 17.9 & 17.7 & 17.8 \\
\hline $\mathbf{1 0 0 0}$ & 18.8 & 18.2 & 18.4 \\
\hline
\end{tabular}

Table 4. Fuel consumption before data adjustment, gear speed 3

\begin{tabular}{|c|c|c|c|c|}
\hline \multirow{2}{*}{$\begin{array}{c}\text { Driving } \\
\text { resistances, }[N]\end{array}$} & \multicolumn{4}{|c|}{ Engine speed, $[1 / \mathrm{min}]$} \\
\cline { 2 - 5 } & $\mathbf{1 5 0 0}$ & $\mathbf{2 0 0 0}$ & $\mathbf{2 5 0 0}$ & $\mathbf{3 0 0 0}$ \\
\cline { 2 - 5 } & \multicolumn{4}{|c|}{ Fuel consumption, $[\mathrm{l} / 100 \mathrm{~km}]$} \\
\hline $\mathbf{2 5 0}$ & 6.8 & 7.2 & 7.1 & 7.8 \\
\hline $\mathbf{5 0 0}$ & 9.6 & 10.4 & 10.1 & 11.1 \\
\hline $\mathbf{7 5 0}$ & 10.3 & 10.8 & 10.9 & 11.4 \\
\hline $\mathbf{1 0 0 0}$ & 11.9 & 13.2 & 12.4 & 13.4 \\
\hline
\end{tabular}

Table 5. Fuel consumption after data adjustment, gear speed 3

\begin{tabular}{|c|c|c|c|c|}
\hline \multirow{2}{*}{$\begin{array}{c}\text { Driving } \\
\text { resistances, }[N]\end{array}$} & \multicolumn{4}{|c|}{ Engine speed, $[1 / \mathrm{min}]$} \\
\cline { 2 - 5 } & $\mathbf{1 5 0 0}$ & $\mathbf{2 0 0 0}$ & $\mathbf{2 5 0 0}$ & $\mathbf{3 0 0 0}$ \\
\cline { 2 - 5 } & \multicolumn{3}{|c|}{ Fuel consumption, $[l / 100 \mathrm{~km}]$} \\
\hline $\mathbf{2 5 0}$ & 6.3 & 7.1 & 7.8 & 9 \\
\hline $\mathbf{5 0 0}$ & 8 & 8.9 & 8.3 & 9.3 \\
\hline $\mathbf{7 5 0}$ & 10.3 & 11.2 & 10.9 & 11.5 \\
\hline $\mathbf{1 0 0 0}$ & 11.1 & 11.6 & 11.1 & 11.8 \\
\hline
\end{tabular}

Table 6. Fuel consumption before data adjustment, gear speed 5

\begin{tabular}{|c|c|c|c|c|}
\hline \multirow{2}{*}{$\begin{array}{c}\text { Driving } \\
\text { resistances, }[N]\end{array}$} & \multicolumn{4}{|c|}{ Engine speed, $[1 / \mathrm{min}]$} \\
\cline { 2 - 5 } & $\mathbf{1 5 0 0}$ & $\mathbf{2 0 0 0}$ & $\mathbf{2 5 0 0}$ & $\mathbf{3 0 0 0}$ \\
\cline { 2 - 5 } & \multicolumn{3}{|c|}{ Fuel consumption, $[l / 100 \mathrm{~km}]$} \\
\hline $\mathbf{2 5 0}$ & 4.6 & 5.1 & 5 & 5.2 \\
\hline $\mathbf{5 0 0}$ & 7.2 & 7.9 & 7.4 & 7.9 \\
\hline $\mathbf{7 5 0}$ & 8.4 & 8.3 & 8.2 & 8.6 \\
\hline $\mathbf{1 0 0 0}$ & 10.4 & 10.6 & 11 & 11.2 \\
\hline
\end{tabular}

Table 7. Fuel consumption after data adjustment, gear speed 5

\begin{tabular}{|c|c|c|c|c|}
\hline \multirow{2}{*}{$\begin{array}{c}\text { Driving } \\
\text { resistances, }[N]\end{array}$} & \multicolumn{4}{|c|}{ Engine speed, $[1 / \mathrm{min}]$} \\
\cline { 2 - 5 } & $\mathbf{1 5 0 0}$ & $\mathbf{2 0 0 0}$ & $\mathbf{2 5 0 0}$ & $\mathbf{3 0 0 0}$ \\
\cline { 2 - 5 } & \multicolumn{3}{|c|}{ Fuel consumption, $[\mathrm{l} / 100 \mathrm{~km}]$} \\
\hline $\mathbf{2 5 0}$ & 4.6 & 5.4 & 5.3 & 5.7 \\
\hline $\mathbf{5 0 0}$ & 6.2 & 6.8 & 6.4 & 7.1 \\
\hline $\mathbf{7 5 0}$ & 8.9 & 8.7 & 8.5 & 9.2 \\
\hline $\mathbf{1 0 0 0}$ & 9.4 & 9.7 & 9.8 & 9.9 \\
\hline
\end{tabular}

Tables 8, 9, 10, 11, 12 and 13 below, represents BSFC in $[g / k W h]$ depending on driving resistance values. The values were recorded also before and after the change of data in the ECU.

Table 8. BSFC before data adjustment, gear speed 1

\begin{tabular}{|c|c|c|c|}
\hline \multirow{2}{*}{$\begin{array}{c}\text { Driving } \\
\text { resistances, }[N]\end{array}$} & \multicolumn{3}{|c|}{ Engine speed, $[1 / \mathrm{min}]$} \\
\cline { 2 - 4 } & $\mathbf{1 5 0 0}$ & $\mathbf{2 0 0 0}$ & $\mathbf{2 5 0 0}$ \\
\cline { 2 - 4 } & Specific fuel consumption, $[\mathrm{g} / \mathrm{kWh}]$ \\
\hline $\mathbf{2 5 0}$ & 1109 & 1481 & 1558 \\
\hline $\mathbf{5 0 0}$ & 664 & 760 & 825 \\
\hline $\mathbf{7 5 0}$ & 501 & 571 & 608 \\
\hline $\mathbf{1 0 0 0}$ & 395 & 440 & 472 \\
\hline
\end{tabular}

Table 9. BSFC after data adjustment, gear speed 1

\begin{tabular}{|c|c|c|c|}
\hline \multirow{2}{*}{$\begin{array}{c}\text { Driving } \\
\text { resistances, }[N]\end{array}$} & \multicolumn{3}{|c|}{ Engine speed, $[1 / \mathrm{min}]$} \\
\cline { 2 - 4 } & $\mathbf{1 5 0 0}$ & $\mathbf{2 0 0 0}$ & $\mathbf{2 5 0 0}$ \\
\cline { 2 - 4 } & Specific fuel consumption, $[\mathrm{g} / \mathrm{kWh}]$ \\
\hline $\mathbf{2 5 0}$ & 1061 & 1541 & 1480 \\
\hline $\mathbf{5 0 0}$ & 586 & 603 & 667 \\
\hline $\mathbf{7 5 0}$ & 453 & 500 & 538 \\
\hline $\mathbf{1 0 0 0}$ & 369 & 393 & 430 \\
\hline
\end{tabular}

Table 10. BSFC before data adjustment, gear speed 3

\begin{tabular}{|c|c|c|c|c|}
\hline \multirow{2}{*}{$\begin{array}{c}\text { Driving } \\
\text { resistances, }[N]\end{array}$} & \multicolumn{4}{|c|}{ Engine speed, [1/min] } \\
\cline { 2 - 5 } & $\mathbf{1 5 0 0}$ & $\mathbf{2 0 0 0}$ & $\mathbf{2 5 0 0}$ & $\mathbf{3 0 0 0}$ \\
\cline { 2 - 5 } & \multicolumn{2}{|c|}{ Specific fuel consumption, $[\mathrm{g} / \mathrm{kWh}]$} \\
\hline $\mathbf{2 5 0}$ & 529 & 687 & 800 & 907 \\
\hline $\mathbf{5 0 0}$ & 336 & 431 & 425 & 469 \\
\hline $\mathbf{7 5 0}$ & 288 & 361 & 372 & 386 \\
\hline $\mathbf{1 0 0 0}$ & 233 & 281 & 284 & 297 \\
\hline
\end{tabular}

Table 11. BSFC after data adjustment, gear speed 3

\begin{tabular}{|c|c|c|c|c|}
\hline \multirow{2}{*}{$\begin{array}{c}\text { Driving } \\
\text { resistances, }[N]\end{array}$} & \multicolumn{4}{|c|}{ Engine speed, [1/min] } \\
\cline { 2 - 5 } & $\mathbf{1 5 0 0}$ & $\mathbf{2 0 0 0}$ & $\mathbf{2 5 0 0}$ & $\mathbf{3 0 0 0}$ \\
\cline { 2 - 5 } & \multicolumn{2}{|c|}{ Specific fuel consumption, $[\mathrm{g} / \mathrm{kWh}]$} \\
\hline $\mathbf{2 5 0}$ & 490 & 677 & 879 & 1.047 \\
\hline $\mathbf{5 0 0}$ & 280 & 369 & 349 & 393 \\
\hline $\mathbf{7 5 0}$ & 288 & 374 & 372 & 389 \\
\hline $\mathbf{1 0 0 0}$ & 217 & 247 & 254 & 262 \\
\hline
\end{tabular}

Table 12. BSFC before data adjustment, gear speed 5

\begin{tabular}{|c|c|c|c|c|}
\hline \multirow{2}{*}{$\begin{array}{c}\text { Driving } \\
\text { resistances, }[N]\end{array}$} & \multicolumn{4}{|c|}{ Engine speed, [1/min $]$} \\
\cline { 2 - 5 } & $\mathbf{1 5 0 0}$ & $\mathbf{2 0 0 0}$ & $\mathbf{2 5 0 0}$ & $\mathbf{3 0 0 0}$ \\
\cline { 2 - 5 } & \multicolumn{2}{|c|}{ Specific fuel consumption, $[\mathrm{g} / \mathrm{kWh}]$} \\
\hline $\mathbf{2 5 0}$ & 386 & 523 & 543 & 575 \\
\hline $\mathbf{5 0 0}$ & 260 & 329 & 328 & 358 \\
\hline $\mathbf{7 5 0}$ & 249 & 281 & 290 & 309 \\
\hline $\mathbf{1 0 0 0}$ & 197 & 235 & 251 & 249 \\
\hline
\end{tabular}

Table 13. BSFC after data adjustment, gear speed 5

\begin{tabular}{|c|c|c|c|c|}
\hline \multirow{2}{*}{$\begin{array}{c}\text { Driving } \\
\text { resistances, }[N]\end{array}$} & \multicolumn{4}{|c|}{ Engine speed, [1/min] } \\
\cline { 2 - 5 } & $\mathbf{1 5 0 0}$ & $\mathbf{2 0 0 0}$ & $\mathbf{2 5 0 0}$ & $\mathbf{3 0 0 0}$ \\
\cline { 2 - 5 } & \multicolumn{2}{|c|}{ Specific fuel consumption, $[\mathrm{g} / \mathrm{kWh}]$} \\
\hline $\mathbf{2 5 0}$ & 386 & 554 & 576 & 630 \\
\hline $\mathbf{5 0 0}$ & 224 & 283 & 284 & 322 \\
\hline $\mathbf{7 5 0}$ & 264 & 295 & 301 & 331 \\
\hline $\mathbf{1 0 0 0}$ & 178 & 215 & 224 & 220 \\
\hline
\end{tabular}


As seen in the Tables 8, 9, 10, 11, 12 and 13, the BSFC has almost the same course in comparison with fuel consumption needed for driving a certain distance.

Tables 14, 15 and 16 shows the percentage of fuel consumption change measured before and after data adjustment. Since there were neither any modification of transmission mechanical efficiency nor of the driving speed, the results in percentage are valid for both, a change of fuel consumption needed for driving a certain distance and a change of BSFC [17-19].

Table 14. Impact of data adjustment on change of fuel consumption, gear speed 1

\begin{tabular}{|c|c|c|c|}
\hline \multirow{2}{*}{$\begin{array}{c}\text { Driving } \\
\text { resistances, }[N]\end{array}$} & \multicolumn{3}{|c|}{ Engine speed, $[1 / \mathrm{min}]$} \\
\cline { 2 - 4 } & $\mathbf{1 5 0 0}$ & $\mathbf{2 0 0 0}$ & $\mathbf{2 5 0 0}$ \\
\cline { 2 - 4 } & Fuel consumption change, [\%] \\
\hline $\mathbf{2 5 0}$ & -4 & 4 & -5 \\
\hline $\mathbf{5 0 0}$ & -12 & -21 & -19 \\
\hline $\mathbf{7 5 0}$ & -10 & -12 & -11 \\
\hline $\mathbf{1 0 0 0}$ & -6 & -11 & -9 \\
\hline
\end{tabular}

Table 15. Impact of data adjustment on change of fuel consumption, gear speed 3

\begin{tabular}{|c|c|c|c|c|}
\hline \multirow{2}{*}{$\begin{array}{c}\text { Driving } \\
\text { resistances, }[N]\end{array}$} & \multicolumn{4}{|c|}{ Engine speed, [1/min] } \\
\cline { 2 - 5 } & $\mathbf{1 5 0 0}$ & $\mathbf{2 0 0 0}$ & $\mathbf{2 5 0 0}$ & $\mathbf{3 0 0 0}$ \\
\cline { 2 - 5 } & \multicolumn{4}{|c|}{ Fuel consumption change, [\%] } \\
\hline $\mathbf{2 5 0}$ & -7 & -1 & 10 & 15 \\
\hline $\mathbf{5 0 0}$ & -17 & -14 & -18 & -16 \\
\hline $\mathbf{7 5 0}$ & 0 & 4 & 0 & 1 \\
\hline $\mathbf{1 0 0 0}$ & -7 & -12 & -10 & -12 \\
\hline
\end{tabular}

Table 16. Impact of data adjustment on change of fuel consumptiongear speed 5

\begin{tabular}{|c|c|c|c|c|}
\hline \multirow{2}{*}{$\begin{array}{c}\text { Driving } \\
\text { resistances, }[N]\end{array}$} & \multicolumn{4}{|c|}{ Engine speed, [1/min] } \\
\cline { 2 - 5 } & $\mathbf{1 5 0 0}$ & $\mathbf{2 0 0 0}$ & $\mathbf{2 5 0 0}$ & $\mathbf{3 0 0 0}$ \\
\cline { 2 - 5 } & \multicolumn{4}{|c|}{ Fuel consumption change, [\%] } \\
\hline $\mathbf{2 5 0}$ & 0 & 6 & 6 & 10 \\
\hline $\mathbf{5 0 0}$ & -14 & -14 & -14 & -10 \\
\hline $\mathbf{7 5 0}$ & 6 & 5 & 4 & 7 \\
\hline $\mathbf{1 0 0 0}$ & -10 & -8 & -11 & -12 \\
\hline
\end{tabular}

For better transparency, the results are also shown in the form of graphs, Fig.5.

The engine speed at which fuel consumption was measured is color-coded. Fig.5 shows the comparison of fuel consumption before and after adjustment of data in the ECU for the first gear speed.

It can be seen that when having a load of $250 \mathrm{~N}$ and engine speed of $2000[1 / \mathrm{min}]$, the fuel consumption has slightly increased after data adjustment. It further has been reduced in the other areas.

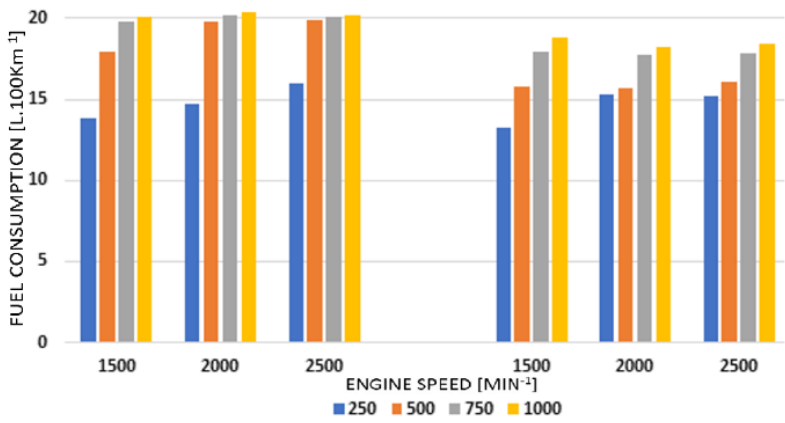

Fig. 5. Comparison of fuel consumption at the first gear speed

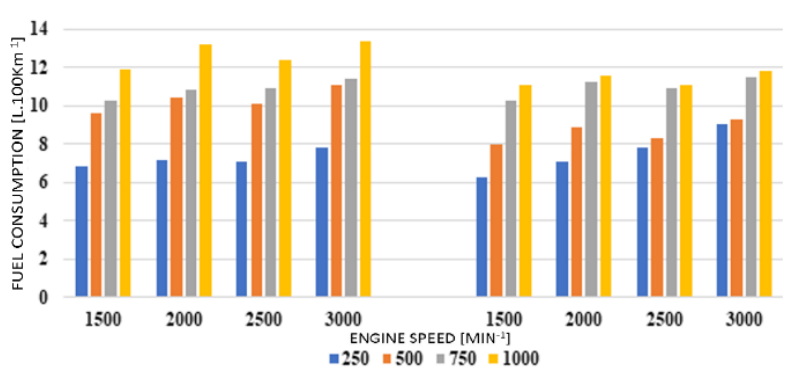

Fig. 6. Comparison of fuel consumption at the third gear speed

When using the third gear speed, the fuel consumption has increased in several aspects, especially in higher speed and lower load, Fig.6.

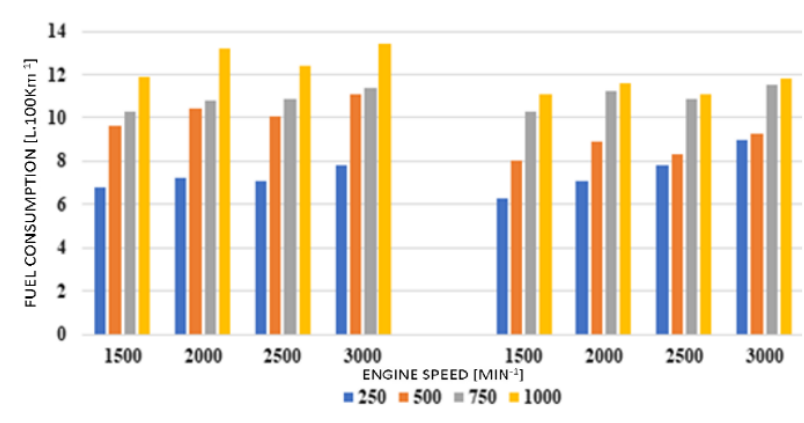

Fig. 7. Comparison of fuel consumption at the fifth gear speed

The fuel consumption measured when having the fifth gear speed used with low engine speed of 1500 and $2000[1 / \mathrm{min}]$ has been reduced after data adjustment, and when having speed of $2500-3000[1 / \mathrm{min}]$, it has increased, except for fuel consumption with a load of $1000 \mathrm{~N}$, Fig.7.

\section{CONCLUSIONS}

The ECUs data adjustment has caused an increase of the engine maximum power and maximum torque. Out of these, the overall course of both curves from the engine speed of about $2200[1 / \mathrm{min}]$ has also increased. 
Therefore, when driving under the above mentioned speed, it is possible to use significantly higher vehicle acceleration as well as higher speed with laden vehicle, also when driving uphill and so on. Before the engine speed of $3000[1 / \mathrm{min}]$ was reached, the transmission control unit had been activated and the engine power and torque had lowered in order to prevent the transmission from damaging. Despite this, both the power and torque curves have had significantly higher course than before data adjustment. The automatic transmission control unit at the engine speed of $2100[1 / \mathrm{min}]$ instructs to use higher transmission gear. Thus, the engine power and torque's increase will be seen only when driving at SPORT mode or during manual gear change.

Data adjustments in the ECU have also led to change of fuel consumption. During measurements, the fuel consumption has been reduced in the majority. Thus, the engine power and torque increase did not automatically and always mean an increase of the amount of fuel consumed, too. The reason is that the combustion efficiency is being increased and, thus, the specific fuel consumption is being reduced [19].

\section{REFERENCES}

[1] Engine control unit software modification and repair.

http://www.profituning.sk/uprava-a-opravasoftveru-v-riadiacej-jednotky-motora (Accessed 05.10.2019).

[2] F. Synák, V. Rievaj, J. Funtíková, M. Pňaček, T. Kutliak, EGR and Selected Vehicle Properties, $8^{\text {th }}$ CMDTUR 2018 conference, 4-5 October, 2018, Žilina, Slovakia.

[3] E. Giakoumis and V. Tziolas, Modeling a VariableGeometry Turbocharged Diesel Engine under Steady-State and Transient Conditions. Journal of Energy Engineering, 144 (3), 2018: 04018017. https://doi.org/10.1061/(ASCE)EY.1943$\underline{7897.0000537}$

[4] Y. Jung and C. Bae, Immaturity of soot particles in exhaust gas for low temperature diesel combustion in a direct injection compression ignition engine. Fuel, 161, 2015: 312-322. https://doi.org/10.1016/i.fuel.2015.08.068

[5] Personal professional data obtained from diagnostic software ESI TRonic 2.0. Internal documentation.

https://www.boschesitronic.com/
[6] B. Šarkan and O. Stopka, Quantification of Road Vehicle Performance Parameters under Laboratory Conditions. Adv. Sci. Technol. Res. J., 12 (3), 2018: 16-23. https://doi.org/10.12913/22998624/92107

[7] Fuel Flow Meter AIC 1200 series, Technical information.

http://reicon.us/TIcurrent/1200/TI\%201000_e_0 7.08.pdf

[8] J. Kosiba, L. Hujo, J. Tulík, M. Rašo, Study of the Impact of Synthetic Fluid on the Lifetime of Hydraulic Pump. Advanced Materials Research, 801, 2013: 7-12.

https://doi.org/10.4028/www.scientific.net/AMR .801 .7

[9] F. Micali, M. Milanese, G. Colangelo and A. De Risi, Experimental investigation on 4-strokes biodiesel engine cooling system based on nanofluid. Renewable Energy, 125, 2018: 319326.

https://doi.org/10.1016/i.renene.2018.02.110

[10] J. Radosavljevic, A. Djordjevic, B. Zlatkovic, B. Samardzic, Compensation of Influence of Protector Compression Coefficients in Tyre Industry. Applied Engineering Letters, 4 (1), 2019: 33-39.

https://doi.org/10.18485/aeletters.2019.4.1.5

[11] V. Rievaj, J. Vrábel, J. Ondruš, Road vehicles (Cestné vozidlá - návody na cvičenia). EDIS vydavatel'ského centra Žilinskej University, University of Žilina, 2014.

[12] B. Šarkan, T. Skrúcaný, Š. Semanová, R. Madleňák, A. Kuranc, M. Sejkorová, J. Caban, Vehicle coast-down method as a tool for calculating total resistance for the purposes of type-approval fuel consumption. Scientific Journal of Silesian University of Technology. Series Transport. 98, 2018: 161-172. https://doi.org/10.20858/sjsutst

[13] J. Ejsmont, W. Owczarzak, Engineering method of tire rolling resistance evaluation. Measurement, 145, 2019: 144-149.

https://doi.org/10.1016/i.measurement.2019.05. $\underline{071}$

[14] B. Šarkan, S. Semanová, V. Harantová, O. Stopka, M. Chovancová, M. Szala, Vehicle fuel consumption prediction based on the data record obtained from an engine control unit. MATEC Web Conf., 252, 2019: 06009, 4 pages. https://doi.org/10.1051/matecconf/2019252060 $\underline{09}$

[15] L. Eriksson, Modeling and Control of Turbocharged SI and DI Engines (Modélisation et contrôle de moteurs suralimentés à allumage commandé et à injection directe). Oil \& Gas Science and Technology - Rev. IFP, 62 (4), 2007: 523-538. 
https://doi.org/10.2516/ogst:2007042

[16] F. Synák, V. Rrievaj, The Impact of Driving Resistances of a Vehicle on Global Pollution in Globalization and its Socio-Econimics Consequences, 17th International Scientific Conference Globalization and Its Socio-Economic Consequences, 4-5 October, 2017, University of Žilina, The Faculty of Operation and Economics of Transport and Communications, Department of Economics.

[17] S. Milojević, T. Skrúcaný, H. Milošević, D. Stanojević, M. Pantić, B. Stojanović, Alternative drive systems and envirnomentaly friendly public passengers transport. Applied Engineering Letters, 3 (3), 2018: 105-113.

https://doi.org/10.18485/aeletters.2018.3.3.4

[18] T. Skrúcaný, M. Kendra, O. Stopka, S. Milojević, T. Figlus, C. Csiszár, Impact of the Electric Mobility Implementation on the Greenhouse Gases Production in Central European Countries. Sustainability, 11 (18), 2019: 4948. https://doi.org/10.3390/su11184948

[19] T. Skrúcaný, Š. Semanová, S. Milojević, A. Ašonja, New technologies iproving aerodynamic properties of freight vehicles. Applied Engineering Letters, 4 (2), 2019: 48-54. https://doi.org/10.18485/aeletters.2019.4.2.2 